\title{
THE IMPACT OF THE MACROECONOMIC SITUATION ON THE LABOUR MARKET IN THE BALTIC STATES IN 2000-2016
}

\section{Abstract}

The accession of the Baltic states to EU structures required a number of structural reforms, including labour market reforms. It should be noted that unemployment in these countries throughout the research period remained high. This condition was largely dependent on the macroeconomic situation of the particular country. An important role was also played by the migration factor.

The aim of this paper is therefore to analyse the impact of the macroeconomic situation on the labour market in the Baltic states.

Keywords: Baltic states, labour market, unemployment, employment, emigration, economic growth.

JEL Classification: A100.

\section{Introduction}

The Baltic countries - Estonia, Latvia and Lithuania - share common features and similar history. After regaining independence in 1991, these three countries quickly opened their small economies to international competition and started their preparations for accession to the European Union (EU). The admission of these countries into the EU in 2004 signified that they had well-functioning democratic systems and competitive market economies. The admission to the Euro area of Estonia in 2011, Latvia in 2014 and Lithuania in 2015 signalled a high degree of convergence in inflation, interest rates, budget balance and public debt. Accession to EU structures required a number of structural reforms, including the labour 
market. It should be noted that unemployment remains persistently high in the Baltic countries. While it has fallen significantly from its post-crisis peak, it remains in the $8-12 \%$ range and is particularly high among young people.

The aim of this paper is to analyse the impact of the macroeconomic situation on the labour market in the Baltic States.

The methodology used in the article is based on an analysis of data provided by the European Statistical Office (Eurostat). Indicators such as: GDP growth in individual countries, the unemployment rate measured as the unemployment rate in relation to the working population, and the employment rate measured as the percentage of the labour force in work were used to assess the labour market situation in the Baltics.

\section{Macroeconomic Situation in the Baltics in 2000-2016}

The Baltics share common development and key structural features: their overall economic situation and policies, the structure of their production, their main trading partners and their population flows underline their similarities but also their differences. Among the conspicuous similarities between the Baltic countries are synchronised economic cycles as well as the overall population decline over recent decades. This situation contrasts with the EU as a whole where the economic cycle has been less pronounced and the population has increased. The three Baltic countries also share a high level of inequality and have the highest Gini coefficients in the EU. Their economic policies are very similar given their common recent history and competition. The adjustment to the market economy after regaining independence followed a similar pattern and all three countries shared a common goal, which was accession to the EU and joining the monetary union. The Baltic states have relatively small government sectors and liberal economic policies. They compete in trade and to attract foreign investment. In practice, foreign investors tend to view the Baltics as a single market and have a single, local headquarters and sales policy for all three countries. In the Baltics, monetary policy and the banking sectors are also very similar. Since the early 1990s, monetary authorities have aimed at stable exchange rates for their currencies. The Estonian Kroon was pegged to the Deutsche Mark from its introduction in 1992. The Latvian Lats was initially pegged to the IMF special drawing rights. The Lithuanian Litas was pegged to the US Dollar starting in 1994. The three Baltic currencies later switched to a peg to the Euro and joined the European exchange rate mechanism (ERMII) 
in 2004 and 2005 before joining the Euro area between 2011 and 2015. The banking sector is the main source of financing for the private sector in the three countries. It is dominated by Nordic banks - Swedbank (Sweden), SEB bank (Sweden), DNB (Norway), Nordea bank (Finland) - which cover a large majority of the banking sector in the three Baltic countries (Staehr 2015; OECD 2003; Kasperowicz-Stępień 2014, pp. 59-70; Stępień \& Kasperowicz-Stępień 2015, pp. 40-48).

It should be noted that after large GDP declines in the early 1990s, the second half of the decade saw rapid economic growth, interrupted only by the fallouts due to the Russian crisis of 1999. The period from 2000 to 2007 was characterised by high and increasing rates of economic growth. This growth spurt came to an end after the onset of the global financial crisis. All three Baltic states were severely affected by the great recession. The decline of their GDP was deeper than that of any other EU country. The crisis was characterised by a housing bubble fuelled by credit supply in all three countries which burst in 2009. Latvia was the most severely affected and required specific assistance regarding its external imbalances. Yet all three countries rapidly experienced a credit-less recovery and are now growing closer to their potential. GDP growth bounced back in 2011-2016 but has since then been at subdued levels (European Commission 2017a; European Commission 2017b; European Commission 2017c; Grajauskas 2014; Kasperowicz-Stępień 2014, pp. 59-70; Stępień \& Kasperowicz-Stępień 2015, pp. 40-48).

Table 1. GDP Growth in the Baltic States in 2000-2016 (Percentage Change Compared with the Previous Period)

\begin{tabular}{l|c|c|c|c|c|c|c|c|c}
\hline \multirow{2}{*}{\multicolumn{1}{c|}{ Specification }} & \multicolumn{10}{c}{ Year } \\
\cline { 2 - 11 } & 2000 & 2002 & 2004 & 2006 & 2008 & 2010 & 2012 & 2014 & 2016 \\
\hline European Union (28) & 3.3 & 2.2 & 2.4 & 2.3 & 0.1 & 2.1 & 2.4 & 1.6 & -1.2 \\
\hline Euro area (19) & 1.3 & 2.4 & 1.9 & 1.9 & 2.1 & 0.7 & 1.2 & 0.9 & 0.8 \\
\hline Estonia & 3.8 & 5.0 & 4.9 & 8.9 & 7.5 & 1.7 & 3.2 & 1.7 & 1.7 \\
\hline Latvia & 15.9 & 1.3 & 2.8 & 12.4 & 11.4 & -1.4 & 5.0 & 1.4 & 0.7 \\
\hline Lithuania & 16.9 & 3.9 & 2.7 & 6.7 & 9.7 & 2.4 & 2.7 & 1.0 & 1.2 \\
\hline
\end{tabular}

Source: http://ec.europa.eu/eurostat/data/database (accessed: 29 August 2017).

The dynamics of economic growth are mirrored in the GDP level per capita in Table 2. The GDP per capita showed a particularly upward trend following the accession of these countries to the structures of the European Union. 
Table 2. GDP Per Capita in the Baltic States in 2000-2016 (Percentage Change Compared with the Previous Period)

\begin{tabular}{l|c|c|c|c|c|c|c|c|c|c}
\hline \multirow{2}{*}{ Specification } & \multicolumn{10}{|c}{ Year } \\
\cline { 2 - 12 } & 2000 & 2002 & 2004 & 2006 & 2008 & 2010 & 2011 & 2012 & 2014 & 2016 \\
\hline $\begin{array}{l}\text { European Union } \\
\text { (28 countries) }\end{array}$ & 3.6 & 1.1 & 2.2 & 2.9 & 0.0 & 1.8 & 1.5 & -0.7 & 1.4 & 1.5 \\
\hline $\begin{array}{l}\text { Euro area } \\
\text { (19 countries) }\end{array}$ & 3.5 & 0.5 & 1.8 & 2.8 & -0.1 & 1.8 & 1.4 & -1.1 & 1.0 & 1.4 \\
\hline Estonia & 8.8 & 6.8 & 7.0 & 10.9 & -5.1 & 2.4 & 7.9 & 4.7 & 3.2 & 1.4 \\
\hline Latvia & 6.4 & 8.4 & 9.5 & 12.9 & -2.6 & -1.7 & 8.4 & 5.3 & 3.1 & 2.8 \\
\hline Lithuania & 4.6 & 7.6 & 7.8 & 9.1 & 3.7 & 3.8 & 8.5 & 5.2 & 4.4 & 3.6 \\
\hline
\end{tabular}

Source: http://ec.europa.eu/eurostat/data/database (accessed: 29 August 2017).

The three countries differ slightly in their economic development and size. Estonia stands out as the most advanced of the three. Its population was only 1.3 million in 2016 (Figure 1) but its GDP per capita was the highest and was about $76 \%$ of the EU28 average in purchasing power parity. The population of Latvia was almost 2 million and GDP per capita was about $64 \%$ of the EU28 average. Lithuania was the largest of the three with 2.9 million inhabitants and a GDP per capita similar to Estonia in PPP about $75 \%$ of the EU28 average.

The Baltic countries have a similar economic structure and, despite their gradual convergence with West European countries, still specialise in the production of low-tech goods. Their agricultural sectors are of similar size and are well above the EU average. The production of goods is mostly based on wood and paper products as well as furniture and textiles, while the production of machinery and transport equipment is significantly lower than the EU average. When looking at specific sectors, one can observe differences in areas of specialisation. While Latvia and Lithuania both have a relatively sizeable food sector, Estonia is the only oil producer of the three and its electronic and electrical equipment industry is relatively more developed. Lithuania also has an important chemical sector, while Latvia specialises in the pharmaceutical industry. Baltic services are mainly connected to the major trade activities in the area. In 2014-2016, trade openness was as high as $160 \%$ of GDP in Estonia and Lithuania, while in Latvia it was around $120 \%$ of GDP; all three are far above the $83 \%$ of GDP for the EU as a whole. Consequently, transportation and storage activities are well developed in these three countries and account for $9 \%$, $13 \%$ and $10 \%$, respectively, of value added compared to only $5 \%$ on average 


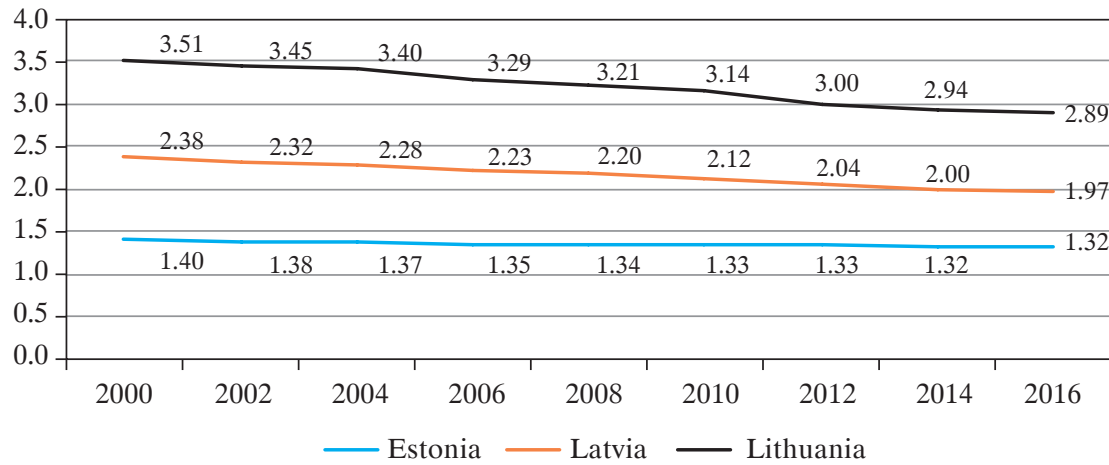

Fig. 1. Population Change in the Baltic States in 2000-2016 in Million Units (Millions of People)

Source: http://ec.europa.eu/eurostat/data/database (accessed: 29 August 2017).

Table 3. Export and Import Share by Trading Partners (Average 2010-2015) in \%

\begin{tabular}{|c|c|c|c|c|c|c|}
\hline \multirow{2}{*}{ Specification } & \multicolumn{2}{|c|}{ Estonia } & \multicolumn{2}{|c|}{ Latvia } & \multicolumn{2}{|c|}{ Lithuania } \\
\hline & Exports & Imports & Exports & Imports & Exports & Imports \\
\hline Baltics & 13 & 11 & 30 & 26 & 16 & 9 \\
\hline Estonia & $\mathrm{n} / \mathrm{a}$ & $\mathrm{n} / \mathrm{a}$ & 13 & 8 & 6 & 3 \\
\hline Latvia & 9 & 5 & $\mathrm{n} / \mathrm{a}$ & $\mathrm{n} / \mathrm{a}$ & 10 & 7 \\
\hline Lithuania & 5 & 6 & 18 & 19 & $\mathrm{n} / \mathrm{a}$ & $\mathrm{n} / \mathrm{a}$ \\
\hline Finland & 14 & 10 & 3 & 5 & 1 & 2 \\
\hline Germany & 4 & 10 & 8 & 12 & 8 & 11 \\
\hline Other Euro area & 9 & 12 & 10 & 15 & 14 & 18 \\
\hline Poland & 2 & 5 & 6 & 9 & 8 & 9 \\
\hline Sweden & 15 & 7 & 6 & 3 & 4 & 3 \\
\hline United Kingdom & 2 & 3 & 4 & 2 & 5 & 2 \\
\hline $\begin{array}{l}\text { Other European } \\
\text { Union non Euro area }\end{array}$ & 3 & 4 & 6 & 5 & 4 & 4 \\
\hline Russia & 15 & 11 & 10 & 9 & 18 & 27 \\
\hline $\begin{array}{l}\text { Other Commonwealth } \\
\text { of Independent States }\end{array}$ & 2 & 2 & 3 & 4 & 8 & 4 \\
\hline USA & 5 & 2 & 1 & 1 & 3 & 1 \\
\hline Japan & 0 & 2 & 0 & 0 & 0 & 0 \\
\hline China & 1 & 7 & 1 & 3 & 0 & 2 \\
\hline Rest of the world & 14 & 14 & 13 & 6 & 14 & 6 \\
\hline
\end{tabular}

Source: https://comtrade.un.org/ (accessed: 29 August 2017). 
in the EU. On the other hand, financial services, business services and public administration are smaller sectors in all three countries (European Commission 2017a; European Commission 2017b; European Commission 2017c; Grajauskas 2014; Kasperowicz-Stępień 2014, pp. 59-70).

Foreign trade by country of origin and destination is displayed in Table 3. Despite their small market size, trade within the Baltic area accounts for 10 to $30 \%$ of each country's exports and imports. There is also a high coincidence of trading partners outside of the Baltics, such as Russia. At the same time, there are some marked differences: Finland and Sweden are more important trading partners for Estonia, while Lithuania and Latvia have larger trade links with Poland (Poissonnier 2017).

\section{Labour Market in the Baltic States in 2000-2016}

The economic growth prior to the crisis had a strong positive impact on the labour market in the Baltic states. Very positive changes took place in the labour market after the 2004 accession to the European Union. The accelerated reforms improved the flexibility of the market and also opened up new financing opportunities through EU funds and government programmes which supported entrepreneurs. The Baltic states also had unusually low labour costs. This resulted in improved competitiveness for workers in the European markets and for the goods and services they produced in the country. The opening of borders led to the possibility of migration, which has resulted in a significant decline in unemployment and in turn led to higher wages and higher standards of living. Unemployment fell to a historic low in early 2008, a rate slightly lower than the average in the EU and Eurozone countries (Ebeke \& Everaert 2014).

Thus, the decline in unemployment in the Baltic countries was largely caused by the migration of citizens to other countries for profit. Hence, there is a slight degree of correlation between the level of unemployment and the size of GDP. This can be demonstrated using statistical methods, for example, the Pearson correlation coefficient, which is a measure of the linear correlation between two variables $X$ and $Y^{1}$. A Pearson correlation is a number between -1 and 1 that indicates the extent to which two variables are linearly related. Using this coefficient, one can examine to what

${ }^{1}$ The correlation coefficient ranges from -1 to 1 . A value of 1 implies that a linear equation describes the relationship between $X$ and $Y$ perfectly, with all data points lying on a line for which $Y$ increases as $X$ increases. A value of -1 implies that all data points lie on a line for which $Y$ decreases as $X$ increases. A value of 0 implies that there is no linear correlation between the variables. 
Table 4. Unemployment in Baltic States in 2000-2016 (\% of the Active Population)

\begin{tabular}{l|c|c|c|c|c|c|c|c|c|c}
\hline \multirow{2}{*}{ Specification } & \multicolumn{7}{c}{ Year } \\
\cline { 2 - 11 } & 2000 & 2002 & 2004 & 2006 & 2008 & 2010 & 2012 & 2014 & 2016 \\
\hline \multicolumn{1}{c}{ Unemployment (\% of the Active Population) } \\
\hline European Union (28 countries) & 8.9 & 9.0 & 9.3 & 8.2 & 7.0 & 9.6 & 10.5 & 10.2 & 8.6 \\
\hline Euro area (19 countries) & 8.9 & 8.6 & 9.3 & 8.4 & 7.6 & 10.2 & 11.4 & 11.6 & 10.0 \\
\hline Estonia & 14.6 & 11.2 & 10.1 & 5.9 & 5.5 & 16.7 & 10.0 & 7.4 & 6.8 \\
\hline Latvia & 14.3 & 12.5 & 11.7 & 7.0 & 7.7 & 19.5 & 15.0 & 10.8 & 9.6 \\
\hline Lithuania & 16.4 & 13.8 & 10.9 & 5.8 & 5.8 & 17.8 & 13.4 & 10.7 & 7.9 \\
\hline \multicolumn{7}{|c|}{ Unemployment of Males (\% of the Active Population) } \\
\hline European Union (28 countries) & 8.1 & 8.4 & 8.6 & 7.6 & 6.6 & 9.7 & 10.4 & 10.1 & 8.4 \\
\hline Euro area (19 countries) & 7.7 & 7.7 & 8.3 & 7.5 & 6.9 & 10.1 & 11.2 & 11.5 & 9.7 \\
\hline Estonia & 15.9 & 12.4 & 11.1 & 6.2 & 5.8 & 19.3 & 10.9 & 7.9 & 7.4 \\
\hline Latvia & 15.3 & 13.2 & 11.5 & 7.3 & 8.4 & 22.7 & 16.2 & 11.8 & 10.9 \\
\hline Lithuania & 18.8 & 14.6 & 10.5 & 6.0 & 6.0 & 21.2 & 15.2 & 12.2 & 9.1 \\
\hline \multicolumn{7}{|c|}{ Unemployment of Females (\% of the Active Population) } \\
\hline European Union (28 countries) & 9.9 & 9.8 & 10.1 & 9.0 & 7.5 & 9.6 & 10.5 & 10.3 & 8.8 \\
\hline Euro area (19 countries) & 10.4 & 9.7 & 10.5 & 9.5 & 8.3 & 10.3 & 11.5 & 11.8 & 10.4 \\
\hline Estonia & 13.3 & 10.0 & 9.1 & 5.6 & 5.1 & 14.1 & 9.1 & 6.8 & 6.1 \\
\hline Latvia & 13.3 & 11.7 & 12.0 & 6.7 & 7.1 & 16.3 & 14.0 & 9.8 & 8.4 \\
\hline Lithuania & 14.0 & 12.9 & 11.3 & 5.6 & 5.6 & 14.5 & 11.6 & 9.2 & 6.7 \\
\hline
\end{tabular}

Youth Unemployment (\% of Unemployment among the Active Population)

\begin{tabular}{l|c|c|c|c|c|c|c|c|c}
\hline European Union (28 countries) & 19.3 & 19.2 & 17.7 & 15.9 & 21.4 & 21.7 & 23.3 & 22.2 & 18.7 \\
\hline Euro area (19 countries) & 19.7 & 18.5 & 17.2 & 16.1 & 21.4 & 21.3 & 23.6 & 23.8 & 20.9 \\
\hline Estonia & 23.9 & 23.9 & 12.1 & 12.0 & 32.9 & 22.4 & 20.9 & 15.0 & 13.4 \\
\hline Latvia & 22.4 & 20.0 & 13.6 & 13.6 & 36.2 & 31.0 & 28.5 & 19.6 & 17.3 \\
\hline Lithuania & 30.0 & 21.8 & 10.0 & 13.3 & 35.7 & 32.6 & 26.7 & 19.3 & 14.5 \\
\hline
\end{tabular}

Long Term Unemployment (\% of the Active Population)

\begin{tabular}{l|c|c|c|c|c|c|c|c|c}
\hline European Union $(28$ countries) & $\mathrm{n} / \mathrm{a}$ & $\mathrm{n} / \mathrm{a}$ & $\mathrm{n} / \mathrm{a}$ & 3.7 & 2.6 & 3.8 & 4.6 & 5.0 & 4.0 \\
\hline Euro area (19 countries) & $\mathrm{n} / \mathrm{a}$ & $\mathrm{n} / \mathrm{a}$ & $\mathrm{n} / \mathrm{a}$ & 3.8 & 2.9 & 4.3 & 5.2 & 6.0 & 5.0 \\
\hline Estonia & 6.7 & 6.1 & 5.2 & 2.9 & 1.7 & 7.6 & 5.5 & 3.3 & 2.1 \\
\hline Latvia & $\mathrm{n} / \mathrm{a}$ & 5.7 & 5.0 & 2.4 & 1.9 & 8.8 & 7.8 & 4.6 & 4.0 \\
\hline Lithuania & $\mathrm{n} / \mathrm{a}$ & 7.4 & 5.6 & 2.6 & 1.3 & 7.4 & 6.6 & 4.8 & 3.0 \\
\hline
\end{tabular}

Source: http://ec.europa.eu/eurostat/data/database (accessed: 29 August 2017). 

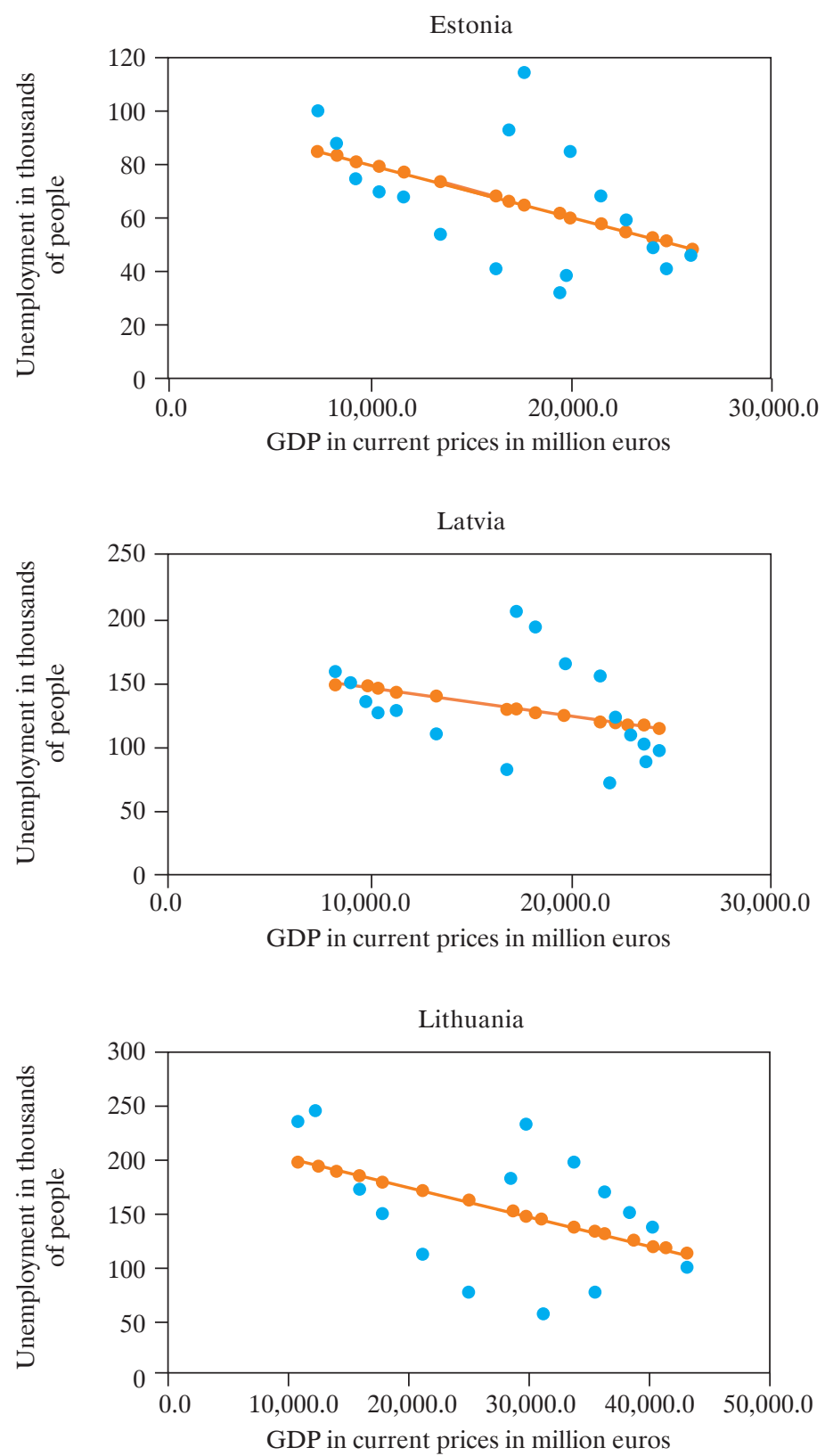

Fig. 2. Correlation between GDP and Unemployment in the Baltic States Source: author's own study based on Pearson's linear correlation coefficient. 
extent two variables such as GDP and unemployment are linearly related. The research sample included the correlation of two variables (GDP and unemployment) over a period of 17 years. Pearson's linear correlation coefficient showed negative values in all the Baltic countries, which means that GDP growth was accompanied by a drop in unemployment. This is also presented on the scatterplot with the aid of a trend line for each of the Baltic States. However, the low level of the indicators shows a weak correlation between the independent variable GDP and the dependent variable unemployment (Figure 2). This means that other factors such as social migration have also had a significant impact on the decline in unemployment.

Pearson's linear correlation coefficient:

- Estonia: -0.497 ;

- Latvia: -0.340 ;

- Lithuania: -0.499 .

The increase in domestic production in the Baltic economies in 20032007 was mainly based on foreign investment and exports (in 2007 their total value reached $35.5 \%$ of GDP, of which as much as one third was accounted for by foreign investment). The economic downturn in global markets resulted in sudden and short-term withdrawal of foreign capital and a fall in demand for export products. This also affected internal production and domestic demand. Latvian, Lithuanian and Estonian GDP decreased by almost 25\% between 2007 and 2009. At the same time, unfavourable phenomena arose on the labour market, such as: a decrease in employment, an increase in unemployment, the freezing of wages and even a reduction in wages. Consequently, the real income of society decreased, the standard of living decreased, and poverty increased. The global crisis forced the governments of Lithuania, Latvia and Estonia to undertake further reforms, such as raising taxes and cutting budget spending, which in turn caused wage freezes and reduced employment in both the private and public sectors. The crisis affected construction workers and the banking sector most severely. However, the problem of migration grew in the time of crisis. After 2004, the population fell drastically: in Estonia by about 6\%, and in Lithuania and Latvia by $13-14 \%$. This resulted in a decrease in unemployment in 2004-2007, but during the crisis a large proportion of emigrants returned to their country due to the difficult economic conditions throughout Europe. It should be noted that the largest social group to leave the Baltic countries for economic reasons in 2004-2007 was uneducated people and young people, and therefore during the crisis they were the ones who contributed 
to the increase in unemployment. There is a great concern about youth unemployment and long-term unemployment, which remains high in the research period (Table 4). In contrast to the average for the European Union and the Euro area countries, unemployment among women in the Baltic states was significantly lower than among men over the analysed period. This is mainly due to a significant reduction in jobs in the construction and industrial sectors.

The growth of economic activity in the Baltic countries, following accession to the EU, also led to significant employment growth in Estonia and Latvia for all age categories and both genders (Figure 3), but especially for women. Among the Baltic states, only Lithuania in 2000-2008 failed to rebuild its labour market. At this time, there was a declining trend in the number of employees.

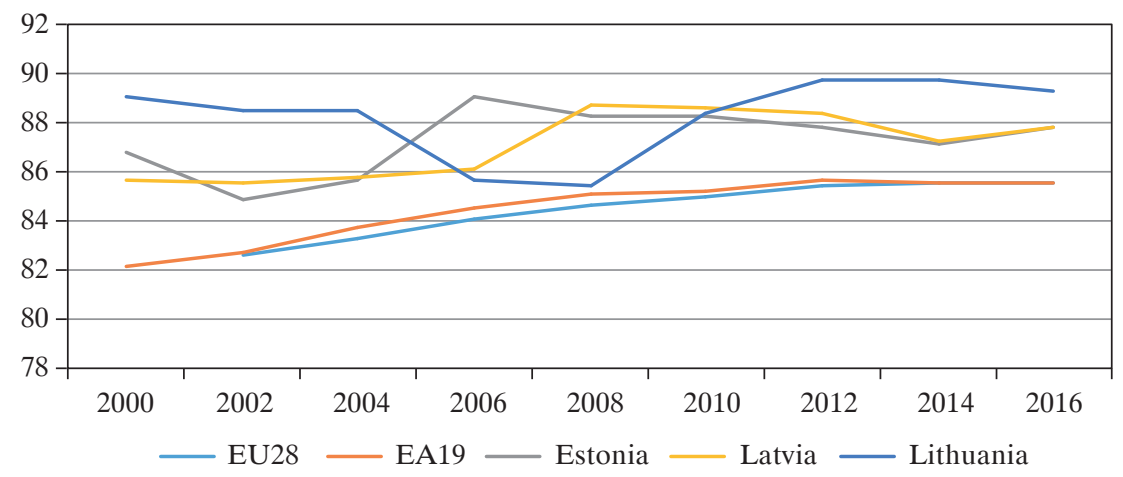

Fig. 3. Employment Growth in Baltic States in 2000-2016 (\% of Active Population) Source: http://ec.europa.eu/eurostat/data/database (accessed: 29 August 2017).

High demand for labour encouraged groups who were previously in a disadvantageous situation, including women, young people and older workers to seize new opportunities. The boom-induced labour shortages also reduced the incidence of long-term unemployment in 2000-2007. Employment thus fell in agriculture and industry, while net job creation was concentrated in the services sector and, in more recent years, in the construction sector. By 2008, the services sector accounted for $60 \%$ of total employment. It was lower than the average in EU countries. The employment share of agriculture and industry in total employment, 4\%-8\% and $27 \%-34 \%$ respectively, was still higher than the average in EU countries (Table 5). 
The crisis of 2008-2009 reduced the number of people employed, possibly due to problems in the services industry. It was only in 2010 that the labour market improved, supported by a growing economy and a sizeable decline in the working-age population (OECD 2010, Purju 2013). Moderate but steady GDP growth was instrumental in the decline of unemployment. The decline in the working-age population was, in turn, the result of an ageing

Table 5. Employment Structure in the Baltic States in 2000-2006

\begin{tabular}{l|c|c|c|c|c|c|c|c|c}
\hline \multirow{2}{*}{ Specification } & \multicolumn{7}{c}{ Year } \\
\cline { 2 - 11 } & 2000 & 2002 & 2004 & 2006 & 2008 & 2010 & 2011 & 2012 & 2014 \\
\hline \multicolumn{7}{c}{ Services (\% of Total Employment) } \\
\hline European Union (28 countries) & 66.1 & 67.6 & 68.7 & 69.5 & 70.1 & 71.8 & 72.1 & 72.5 & 73.1 \\
\hline Euro area (19 countries) & 69.1 & 70.0 & 71.0 & 71.7 & 72.5 & 74.1 & 74.5 & 74.8 & 75.4 \\
\hline Estonia & 60.5 & 62.3 & 60.4 & 62.4 & 61.7 & 66.9 & 64.6 & 65.7 & 67.4 \\
\hline Latvia & 60.7 & 59.6 & 62.9 & 62.4 & 65.3 & 68.8 & 68.2 & 68.1 & 68.8 \\
\hline Lithuania & 55.0 & 55.3 & 56.4 & 55.6 & 61.5 & 66.6 & 67.0 & 66.1 & 66.1 \\
\hline \multicolumn{7}{|c|}{ Industry (\% of Total Employment) } \\
\hline European Union (28 countries) & 26.2 & 25.7 & 25.1 & 24.7 & 24.5 & 22.8 & 22.7 & 22.4 & 21.9 \\
\hline Euro area (19 countries) & 26.2 & 25.6 & 24.9 & 24.4 & 24.0 & 22.4 & 22.1 & 21.8 & 21.2 \\
\hline Estonia & 32.8 & 30.9 & 33.8 & 32.8 & 34.4 & 28.9 & 31.0 & 29.8 & 28.8 \\
\hline Latvia & 24.7 & 25.6 & 26.4 & 27.3 & 27.1 & 23.3 & 23.8 & 24.0 & 23.7 \\
\hline Lithuania & 26.4 & 27.1 & 28.0 & 30.6 & 30.5 & 24.6 & 24.6 & 25.1 & 24.7 \\
\hline \multicolumn{7}{|c|}{ Agriculture (\% of Total Employment) } \\
\hline European Union (28 countries) & 7.7 & 6.7 & 6.2 & 5.7 & 5.4 & 5.4 & 5.2 & 5.1 & 5.0 \\
\hline Euro area (19 countries) & 4.7 & 4.4 & 4.1 & 3.9 & 3.6 & 3.5 & 3.5 & 3.4 & 3.4 \\
\hline Estonia & 6.6 & 6.8 & 5.8 & 4.8 & 3.9 & 4.2 & 4.4 & 4.5 & 3.7 \\
\hline Latvia & 14.6 & 14.8 & 10.8 & 10.3 & 7.6 & 7.8 & 8.0 & 7.8 & 7.4 \\
\hline Lithuania & 18.6 & 17.7 & 15.6 & 13.8 & 8.0 & 8.8 & 8.5 & 8.8 & 9.2 \\
\hline
\end{tabular}

Source: http://ec.europa.eu/eurostat/data/database (accessed: 29 August 2017).

Table 6. The International Migration Balance in the Baltic States in 2000-2006

\begin{tabular}{l|c|c|c|c|c|c|c|c|c}
\hline \multirow{2}{*}{ Country } & \multicolumn{10}{c}{ Year } \\
\cline { 2 - 11 } & 2000 & 2002 & 2004 & 2006 & 2008 & 2010 & 2012 & 2014 & 2016 \\
\hline Estonia & -2.3 & -2.2 & -2.7 & -4.0 & -1.5 & -2.8 & -2.8 & -0.5 & 0.8 \\
\hline Latvia & -6.9 & -4.0 & -6.8 & -4.0 & -10.3 & -17.0 & -5.8 & -4.3 & -6.2 \\
\hline Lithuania & -5.8 & -3.4 & -9.5 & -7.5 & -5.1 & -25.2 & -7.1 & -4.2 & -10.5 \\
\hline
\end{tabular}

Source: http://ec.europa.eu/eurostat/data/database (accessed: 29 August 2017). 
164 Alicja Kasperowicz-Stępień

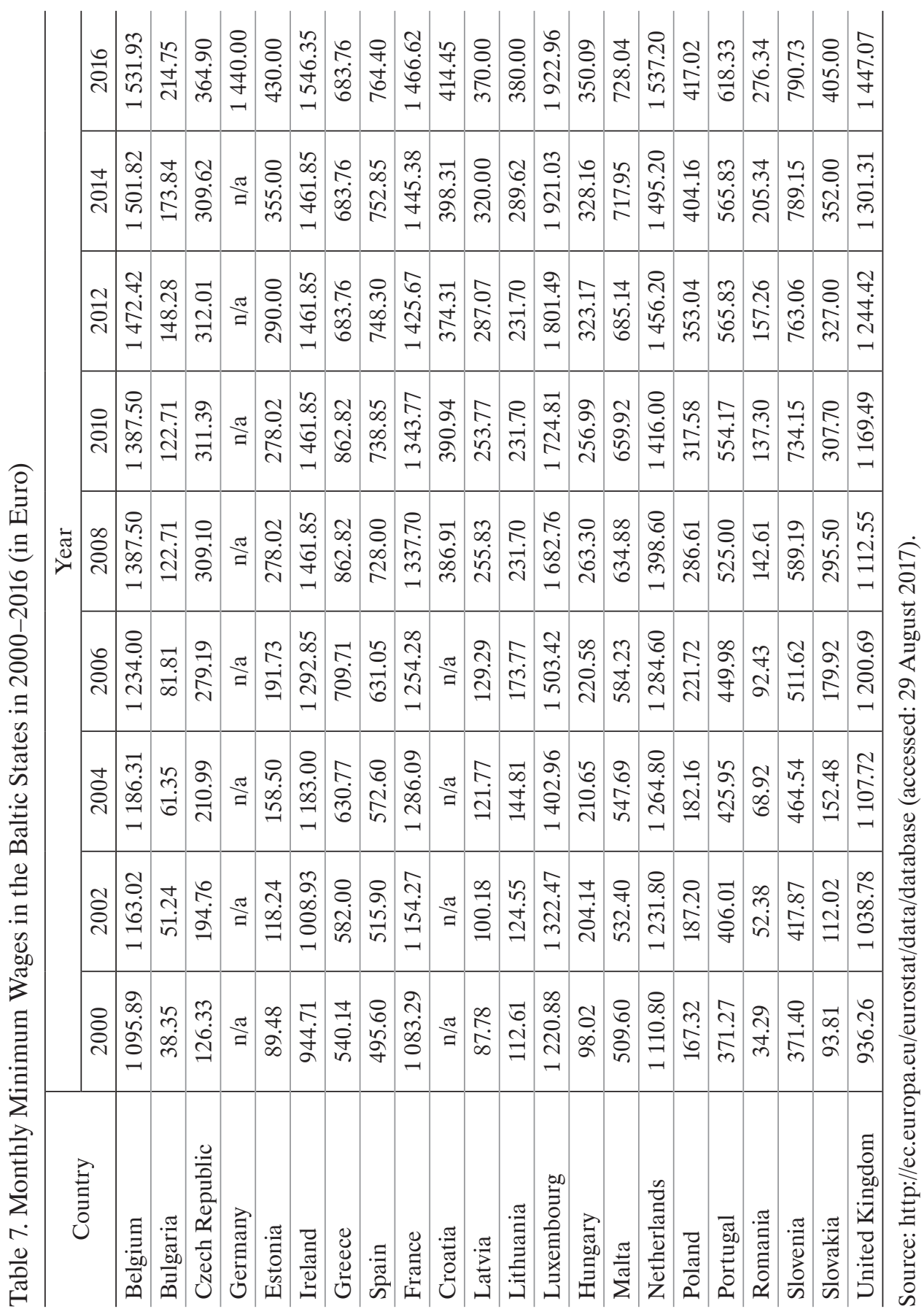


population and persistent net emigration (Hazans 2011, Aidukaite 2011). The international migration balance continued to be negative (Table 6). Nevertheless, the unemployment rate in 2010-2016 remained above its pre-crisis level.

The reasons for the high level of emigration in the Baltic states were: the difficulty in finding a job due to the low number of job offers, failure to meet the criteria and expectations of employers, the low level of wages (the minimum wage in the Baltic states is one of the lowest in the EU Table 7), and the impoverishment of society ${ }^{2}$. This led to the situation that a large proportion of the population (particularly young people) did not see a future for themselves in these countries. That is why many people chose to leave their country to seek work, especially in West European countries (Gruzevskis \& Blaziene 2013, Lulle 2013, Aidukaite 2011).

The problems of increasing emigration have put Lithuania, Latvia and Estonia in a complex situation. While heavy emigration may provide limited short-term relief to the region's unemployment problems, the region's demographic issues will pose serious economic and political challenges in the long run.

Therefore, Baltic countries will have to deal with a shrinking workforce and a growing number of retirees - factors that will reduce each country's tax base while increasing fiscal pressure on governments, since the latter will need to devote greater resources to areas such as pensions and health care. Demographic change will also lead to growing competition for skilled and semi-skilled workers in Europe. Unless they can find ways to keep their most valuable workers at home, Baltic countries will likely be among the losers in the EU-wide race for workers.

\section{Conclusions}

Facing high unemployment (especially among young people), modest incomes and a more unequal income distribution than in many European countries, Baltic policy-makers have limited room for manoeuvre. In employment policy, the chief goal must be to improve the institutional framework for innovation and job creation. Most elements of the labour market and social policy have been thoroughly reformed over the past decade. For obvious reasons, reform activity until now has been largely inspired by policy examples set in EU countries. However, policy-makers

\footnotetext{
${ }^{2}$ For comparison, labour costs in other EU countries and in Poland are discussed in European Commission (2017d) and in Maślanka (2010, 2011).
} 
must also take into account the more difficult situation in the Baltic states, the market with a significantly low labour supply, modest living standards and relatively unequal income distributions. Social spending needs to be contained because taxes and social insurance contributions are relatively high, placing a heavy burden on employment.

Finding a solution to unemployment depends mainly on whether it reflects cyclical or structural factors. Policies to address cyclical unemployment primarily focus on demand management. However, addressing structural unemployment tends to require deep and targeted reforms that tackle the underlying forces of why the unemployed do not find their way to jobs that match their skills and expectations).

The governments of the Baltic countries should look for new solutions to combat unemployment, raise standards of living, and improve life prospects for citizens (especially for young people) as well as create a support programme for the poorest households.

\section{Bibliography}

Aidukaite, J. (2011) "Welfare Reforms and Socio-economic Trends in the 10 New EU Member States of Central and Eastern Europe". Communist and Post-Communist Studies 44(3): 211-19, https://doi.org/10.1016/j.postcomstud.2011.07.005.

Ebeke, Ch. and Everaert, G. (2014) "Unemployment and Structural Unemployment in the Baltics". IMW Working Paper 14/153, https://doi.org/10.5089/9781498317207.001.

European Commission (2017a) "Country Report Estonia 2017”. Brussels: Commission Staff Working Document.

European Commission (2017b) "Country Report Latvia 2017”. Brussels: Commission Staff Working Document.

European Commission (2017c) "Country Report Lithuania 2017". Brussels: Commission Staff Working Document.

European Commission (2017d) "Wages and Labour Costs". Eurostat Statistics Explained.

Grajauskas, R. (2014) Baltic Economies in 2015-2016. Lithuania: Danske Bank.

Gruzevskis, B. and Blaziene, I. (2013) "Social and Employment Situation in Lithuania". Brussels: European Parliament, http://ec.europa.eu/eurostat/data/database (accessed: 29 August 2017).

Hazano, M. (2011) "The Changing Face of Latvian Emigration, 2000-2010", in B. Zepa and E. Klave (eds) Latvia. Human Development Report 2010/2011: National Indentity, Mobility and Capability. Riga: University of Latvia Press, pp. 77-101.

Kasperowicz-Stępień, A. (2014) "Sytuacja makroekonomiczna oraz stan finansów publicznych w krajach nadbałtyckich w latach 2003-2012" [Macroeconomic situation and the state of public finances in the Baltic Countries in the years 20032012] in S. Owsiak (ed.) Finanse w polityce makroekonomicznej państwa [Finances 
in the macroeconomic policy of the state]. Kraków: Wydawnictwo Uniwersytetu Ekonomicznego w Krakowie.

Lulle, A. (2013) "Baltic Triplets? Out-Migration and Responses to Crisis". Regional Formation and Development Studies 11(3), https://doi.org/10.15181/rfds.v11i3.616.

Maślanka, T. (2010) "Koszty pracy a rentowność polskich przedsiębiorstw przemysłowych” [Labour costs and the profitability of Polish industrial enterprises] in J. Ostoj (ed.) W poszukiwaniu źródet finansowania rozwoju przedsiębiorstw oraz jednostek samorzadu terytorialnego $w$ warunkach kryzysu finansowego [In search of sources of financing for the development of enterprises and local government units in the conditions of financial crisis]. Bielsko-Biała: Wyższa Szkoła Bankowości i Finansów w BielskuBiałej, Bielsko-Biała, pp. 82-88.

Maślanka, T. (2011) "Koszty wynagrodzeń a rentowność polskich przedsiębiorstw” [Wage costs and the profitability of Polish enterprises] in J. Ostoj (ed.) Ryzyko kryzysu we wspótczesnej gospodarce - mechanizmy i środki zaradcze [The risk of crisis in the modern economy - mechanisms and remedies]. Zeszyty Naukowe Wyższej Szkoły Bankowości i Finansów w Bielsku-Białej, No 4, pp. 70-76.

OECD (2003) Labour Market and Social Policies in the Baltic Countries, https://doi. org/10.1787/9789264100077-en.

OECD (2010) Reviews of Labour Market and Social Policies. Estonia. 2010, https://doi. org/10.1787/9789264082120-en.

Poissonnier, A. (2017) The Baltics: Three Countries. One Economy? Brussels.

Purju, A. (2013) Economic and Social Development in the Baltic States. Brussels: European Economic and Social Committee.

Staehr, K. (2015) "Economic Growth and Convergence in the Baltic States: Caught in a Middle-Income Trap?" in Joining the Euro and Then? How to Ensure Economic Success after Entering the Common Currency. Vilnius.

Stępień, K. and Kasperowicz-Stępień, A. (2015) "Public Sector Accounting System Reform in Baltic States - the Case of Lithuania and Estonia" in IFRS: Global Rules\&Local Use. Prague: Anglo-American University.

\section{Abstract}

\section{Wplyw sytuacji makroekonomicznej na rynek pracy w krajach nadbaltyckich w latach 2000-2016}

Przystąpienie państw nadbałtyckich do struktur Unii Europejskiej wymagało przeprowadzenia licznych reform strukturalnych, w tym reformy rynku pracy. Należy zauważyć, że bezrobocie w tych krajach w całym okresie badawczym utrzymywało się na wysokim poziomie. Taki stan uzależniony był w dużej mierze od sytuacji makroekonomicznej kraju. Celem artykułu jest zatem analiza wpływu sytuacji makroekonomicznej na rynek pracy w krajach nadbałtyckich.

Słowa kluczowe: kraje bałtyckie, rynek pracy, bezrobocie, zatrudnienie, emigracja, wzrost gospodarczy. 